\title{
QUALITY OF HIGHER EDUCATION ONLINE TRAINING, STUDENT SATISFACTION AND LOYALTY IN THE CONTEXT OF THE COVID-19 PANDEMIC. A VIETNAMESE PERSPECTIVE
}

\author{
Nguyen Thi Hoai Trinh \\ Bucharest University of Economic Studies \\ hoaitrinh.hce@gmail.com
}

\begin{abstract}
The study aims to test the online training quality scale and examine the relationship between training quality, satisfaction, and loyalty of online students. The results of CFA analysis on a survey sample of 300 online students of public and non-public universities in Hanoi city. The online training quality scale includes five components: (1) quality of information systems (2) quality of faculty, (3) effectiveness of online learning, (4) student satisfaction, and (5) student loyalty. Furthermore, the results of SEM analysis show that the quality of the information system, the quality of the lecturers, and the effectiveness of online learning all have an indirect relationship to loyalty, and directly for satisfaction, and anthropological factors are time and place of residence affect learners' satisfaction.
\end{abstract}

Keywords: Training quality, Online, Satisfaction, Loyalty, Covid-19

DOI: https://doi.org/10.24818/beman/2021.S.I.2-06

\section{INTRODUCTION}

In the context that humanity is moving towards a knowledge economy, higher education is considered as a cradle for training quality human resources. However, the outbreak of the covid-19 pandemic has dominated all aspects of society, including higher education. With the criteria of safe distance, the restriction of direct contact and travel restrictions are being encouraged to protect the health of individuals and the community. Therefore, it can be said that the Covid-19 pandemic poses various challenges to the education and training system of Vietnam. Faced with the fact that schools must be closed due to the epidemic, educational institutions and teachers must adopt online training to connect with students and ensure continuity of teaching (Ali, 2020).

Covid-19 has facilitated learning solutions (Vlachopoulos, 2020), and the Internet has become one of the most important and popular means of making resources available for learning and research to teachers and students to exchange information (Richard \& Haya, 2009). The pandemic period is also challenging for higher education institutions in ensuring the quality of teaching services when switching from traditional to online (Ramírez-Hurtado et al., 2021). The evaluation of service quality of an educational institution will 
be directly assessed by customers, i.e. learners, through satisfaction. Therefore, student satisfaction is the primary basis for leading the competition and has become an important university goal (Arambewela \& Hall, 2006). This satisfaction is also a factor leading to learners' loyalty decisions when standing among peer choices. Therefore, it is crucial to pay attention and research the quality of online teaching services so that in any circumstances, in any form of teaching, higher education institutions can still meet the quality of their educational services. Moreover, if the educational institution provides good online training services, this will be a form of training not only in the Covid period but also Post-Covid; it is still a suitable form for groups of subjects who have learning needs without being forced in terms of space, for example, for subjects who study while working, etc.

The global impact of e-learning is changing pedagogy and making it easier to learn across spaces because this change can create changes in students' perception of their perception that may be different from before when receiving knowledge from traditional teaching, also an opportunity for educational institutions to rethink the quality of services in general and the quality of teachers in particular. Therefore, through this article, we aim to capture the existence of factors affecting the service quality of educational institutions, and further, the school's brand through learners' perspective during the Covid-19 pandemic. Besides, the study also found the relationship between the factors determining the quality of training services to the satisfaction and loyalty of students in online training. The main research method is quantitative analysis with structural equilibrium modelling (SEM) techniques. The author has identified all three main factors to assess the quality of training services that positively influence student satisfaction in the online training environment. The three main factors are Quality of online information system, Quality of teaching staff, and Effective online training. Research also shows that student satisfaction is the foundation of student loyalty in the online training environment. Moreover, student loyalty is indirectly influenced by the factors that evaluate the quality of training services. The research results are the basis for higher education institutions to perfect appropriate policies in improving the quality of higher education and training institutions in the future.

\section{LITERATURE REVIEW}

According to several studies (Zeithaml, 1988), service quality is defined as "the customer's overall assessment of service excellence and superiority." Some authors (Parasuraman et al.., 1985) say that "Quality service is the gap between customers' expectations and their perceptions when they have used the service." Another study (Jun \& Cai, 2001) proposed factors when researching the quality of traditional education taught in the online environment: reliability, accessibility, ease to use, personal, confidentiality, credibility, and responsiveness. In the context of evolving digital technology, online training is a form of training of choice because of its responsiveness and convenience, student-centeredness, and greater 
flexibility (Dhawan, 2020). Online training can be understood as training with a gap in time and space between students and teachers (Verduin \& Clark , 1991). This type of training emphasizes the flexibility of the education system, minimizing barriers caused by age, geographical location, time constraints, and financial status (Belawati \& Baggaley, 2009). The benefits of information and communication technology have created a broader way of thinking about distance learning development in the future. The problem of distance between teachers and students is solved by modern technology; teachers and students are not confined in a classical classroom space; instead, it is a time-synchronous interaction over a larger space, ignore the distance factor and overcome the time barrier (Belawati \& Baggaley, 2009). However, the ultimate goal of education is to train quality human resources, which depends a lot on the quality of service in higher education in which students are considered customers. Some authors (Hill, 1995) argue that for a university, the student is mentioned as a major customer of higher education services; universities should focus on the student's expectations as well as the desire to serve. Moreover, students are the ones who go to educational institutions to contact them, spending money to buy the knowledge and learning support services they provide (Griffin, 1996). Grossman (1999) argues that students should be treated as customers in the school and that schools should prioritize meeting the expectations and needs of students. Therefore, for higher education, more attention should be paid to satisfying needs and keeping students on campus, and it is the response based on students' expectations that leads to an inevitable outcome of the experience, which is satisfaction (Parker \& Ward, 2000). Another interesting study (Browne et al., 1998) found that student satisfaction depends on the quality of the course, teaching activities, and other university-related factors in universities. According to Chute, Thompson, \& Hancock (1999), student satisfaction is an important psychological factor contributing to students' academic success. Therefore, the process of building student satisfaction is cumulative over time (Oliver, 1997), psychological and leads to brand commitment, which is loyalty (Bloemer et al., 1998). Of course, customer satisfaction is not synonymous with loyalty (Bowen \& Chen, 2001), but it is only a driving force to determine customer loyalty. There are many studies on service quality and satisfaction or loyalty, but these studies only examine the direct relationship between factors for satisfaction or loyalty. This study is based on the scale of previous studies, adding new factors suitable to the research conditions and purposes to find out the indirect relationship between the factors of the quality of online education and training services and of loyalty. 


\section{RESEARCH METHODOLOGY}

\subsection{Data collecting}

The data were collected at Thai Nguyen University in the northern mountainous region of Vietnam. The survey subjects are students who are studying all systems at this school; samples were collected by the convenience sampling method (Zhuo, et al., 2021) and completely voluntary (Garvey, et al., 2021). According to Leslie \& Brinkman (1987), higher education is considered as a special market for goods and services. In this point of view, students are the customers who are receiving services from the educational institution. Therefore, the student survey is entirely consistent with the study's criteria when it is an individual in the population of interest (Peterson \& Merunka, 2014).

In order to ensure safety during the covid-19 pandemic with social distancing guidelines, the questionnaire was sent through the google forms app. In addition, the author contacted a number of groups of students and lecturers at the university to help transfer the questionnaire to the research subjects. The number of votes collected was 368 votes, except for invalid votes; there were 316 votes left.

\subsection{Instrument and Variables}

Data were extracted from a structured questionnaire, in which the author used the Rensis Likert scale (Likert, 1932). Likert presents scales with levels of $3,5,7, \ldots$ depending on the sample size. The scale in this study is built on 5 levels, specifically as follows:
1- $\quad$ Totally disagree.
4- $\quad$ Agree.
2- $\quad$ Disagree.
5- $\quad$ Totally agree.
3- Neutral.

The questionnaire consists of 31 items grouped into 5 main groups, as follows: quality of online information system, quality of lecturers, the effectiveness of online learning, student satisfaction, student loyalty.

TABLE 1: DIMENSIONS AND ATTRIBUTED SELECTED TO MEASURE

\begin{tabular}{|c|c|c|c|}
\hline Symbol & Main factor & Variable name & Origin of scale \\
\hline \multirow{5}{*}{ QOIS } & \multirow{5}{*}{$\begin{array}{l}\text { Quality of online } \\
\text { information } \\
\text { system }\end{array}$} & Easy to login & \multirow{5}{*}{$\begin{array}{c}\text { (Jun \& Cai, 2001); } \\
\text { (Abdalla, 2007) } \\
\text { (Han \& Beak, 2004) }\end{array}$} \\
\hline & & Streamlined, clear interface & \\
\hline & & Security & \\
\hline & & Up to date calculation & \\
\hline & & Support Services & \\
\hline \multirow{4}{*}{ LQ } & \multirow{4}{*}{ Lecturers quality } & Lecturer qualifications & \multirow{4}{*}{$\begin{array}{c}\text { (Sher, 2009); } \\
\text { (Ali \& Ahmad, 2011); } \\
\text { (Delone \& McLean, } \\
\text { 2003), } \\
\text { (Ho \& Dzeng, 2010) }\end{array}$} \\
\hline & & Responsiveness & \\
\hline & & Interoperability & \\
\hline & & Evaluation and testing activities & \\
\hline
\end{tabular}


Nguyen, $T$.

QUALITY OF HIGHER EDUCATION ONLINE TRAINING, STUDENT SATISFACTION AND LOYALTY IN THE CONTEXT OF THE COVID-19 PANDEMIC. A VIETNAMESE PERSPECTIVE

\begin{tabular}{|c|c|c|c|}
\hline \multirow{4}{*}{ OLE } & \multirow{4}{*}{$\begin{array}{l}\text { The effectiveness } \\
\text { of online learning }\end{array}$} & Ensuring health & \multirow{4}{*}{$\begin{array}{c}\text { (Delone \& McLean, } \\
\text { 2003); } \\
\text { (Belawati \& Baggaley, } \\
\text { 2009). } \\
\text { (Liaw, 2008) }\end{array}$} \\
\hline & & Minimize barriers of space, time, finance & \\
\hline & & Proactivity & \\
\hline & & Concentration & \\
\hline \multirow{4}{*}{ SS } & \multirow{4}{*}{$\begin{array}{l}\text { Student } \\
\text { satisfaction }\end{array}$} & $\begin{array}{l}\text { I am satisfied with the online application I am } \\
\text { using }\end{array}$ & \multirow{4}{*}{$\begin{array}{c}\text { (Han \& Beak, 2004); } \\
\text { (Lee, 2010); } \\
\text { (Delone \& McLean, } \\
\text { 2003) }\end{array}$} \\
\hline & & I am satisfied with the quality of lecturers & \\
\hline & & $\begin{array}{l}\text { I am satisfied with the quality of service support } \\
\text { of the educational institution }\end{array}$ & \\
\hline & & Online teaching fully meets my learning needs & \\
\hline \multirow{4}{*}{ LC } & \multirow{4}{*}{$\begin{array}{l}\text { Learner } \\
\text { characteristics }\end{array}$} & $\begin{array}{c}\text { There is a gender difference in student } \\
\text { satisfaction in online learning }\end{array}$ & \multirow{4}{*}{ Author's proportion } \\
\hline & & $\begin{array}{l}\text { There is an age difference in student satisfaction } \\
\text { in online learning }\end{array}$ & \\
\hline & & $\begin{array}{l}\text { The number of hours of online learning affects } \\
\text { student satisfaction }\end{array}$ & \\
\hline & & $\begin{array}{c}\text { There is a difference in residence that affects } \\
\text { student satisfaction in online learning }\end{array}$ & \\
\hline \multirow[b]{2}{*}{ LY } & \multirow[b]{2}{*}{ Loyalty } & I volunteer to use this app & \multirow{2}{*}{$\begin{array}{c}\text { (Helgesen \& Nesset, } \\
\text { 2007); (Thomas \& } \\
\text { Rogers, 2020) }\end{array}$} \\
\hline & & $\begin{array}{l}\text { I will recommend to others about this form of } \\
\text { learning }\end{array}$ & \\
\hline
\end{tabular}

Source: the authors synthesize

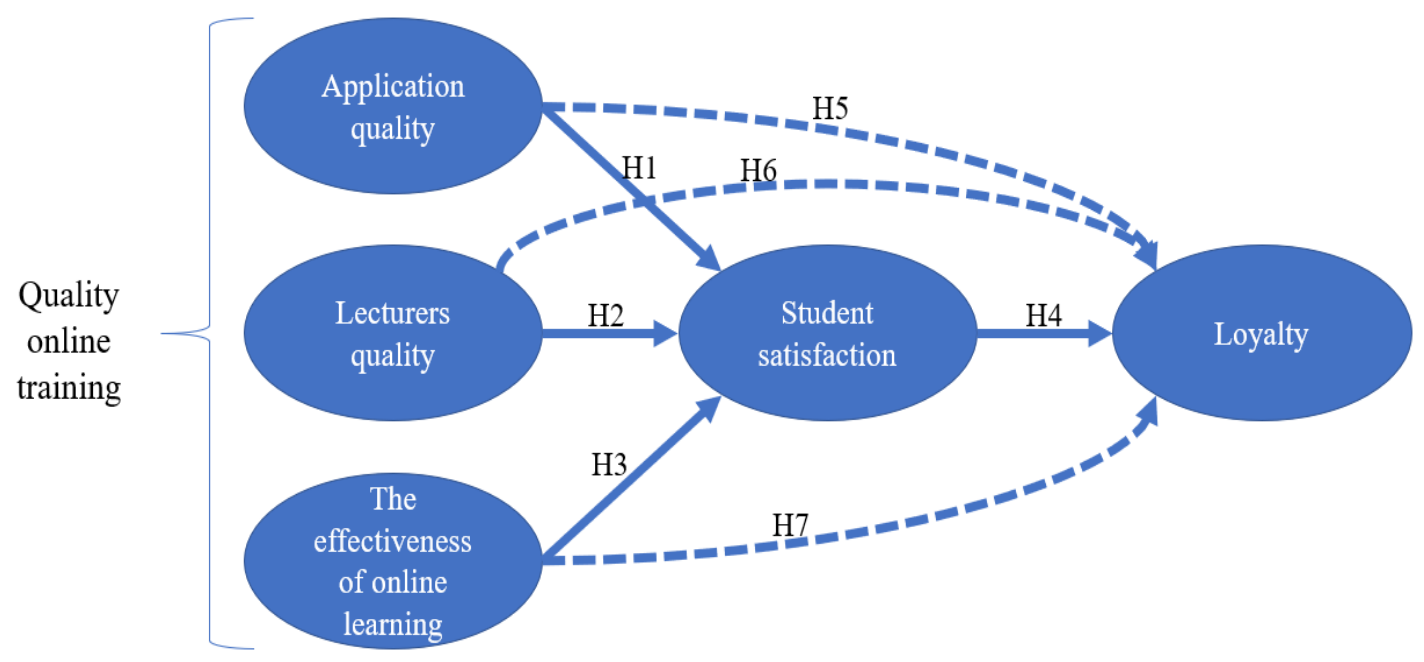

FIGURE 1: RESEARCH MODEL

Source: Authors' own conception

Based on the research model, the author proposes the research hypotheses:

H1: Application quality has a direct impact on student satisfaction

$\mathrm{H} 2$ : Teaching quality has a direct impact on student satisfaction

H3: Effectiveness of online learning has a direct impact on student satisfaction 
Nguyen, T.

QUALITY OF HIGHER EDUCATION ONLINE TRAINING, STUDENT SATISFACTION AND LOYALTY IN THE CONTEXT

OF THE COVID-19 PANDEMIC. A VIETNAMESE PERSPECTIVE

H4: Satisfaction has a direct impact on student loyalty

H5: Application quality has an indirect impact on student loyalty

H6: Teaching quality has an indirect impact on student loyalty

$\mathrm{H7}$ : Effectiveness of online learning has an indirect impact on student loyalty

\subsection{Statistical Analysis}

Data were analyzed using SPSS software. First, the scale was preliminarily evaluated by Cronbach Alpha reliability coefficient and EFA exploratory factor analysis with the help of SPSS software. In EFA analysis, the Principal Axis Factoring extraction method with Promax rotation was used. Next, the scales were tested by confirmatory factor analysis (CFA). Finally, the SEM method through AMOS software is used to test the theoretical model and the hypotheses.

\section{RESULTS AND DISCUSSION}

\subsection{Introduction of the research sample.}

TABLE 2. THE STUDY SAMPLE CHARACTERISTICS

\begin{tabular}{|c|c|c|c|}
\hline Question & Answer & Number of Votes & Percentage \\
\hline \multirow{2}{*}{ Gender } & Male & 126 & 39,9 \\
\hline & Female & 190 & 60,1 \\
\hline \multirow{4}{*}{ Age } & Under 20 & 164 & 51,9 \\
\hline & $20-24$ & 85 & 26,9 \\
\hline & $25-34$ & 55 & 17,4 \\
\hline & $35-44$ & 12 & 3,8 \\
\hline \multirow{4}{*}{$\begin{array}{l}\text { Working } \\
\text { hours }\end{array}$} & Less than 5 hours per day & 217 & 68,7 \\
\hline & 5-8 hours per day & 40 & 12,7 \\
\hline & 8-10 hours per day & 56 & 17,7 \\
\hline & Above 10 hours per day & 3 & 0,9 \\
\hline \multirow{4}{*}{ Residence } & $\begin{array}{c}\text { Ethnic minority, mountainous, coastal, border, island } \\
\text { areas. (Area 1) }\end{array}$ & 118 & 37,3 \\
\hline & $\begin{array}{l}\text { Towns and cities directly under the province or towns } \\
\text { and districts of a city under central authority (Area 2) }\end{array}$ & 112 & 35,4 \\
\hline & Urban districts of centrally affiliated cities (Area 3) & 39 & 12,3 \\
\hline & The rest of the localities (Rural Area 2) & 47 & 14,9 \\
\hline
\end{tabular}

Source: Authors' own calculation 
Statistical analysis results show that $39.9 \%$ of the respondents are male, and $60.1 \%$ are female. Regarding the age, when the Covid-19 pandemics occurred, all students in formal or semi-formal training systems or studying and working at the same time switched to online learning. According to the assessment results on age, $51.9 \%$ of students are under 20 years old, which is the age group of those who have just graduated from high school for 1-2 years; The age group from 20-24 accounts for $26.9 \%$, which is the age group of students who mainly study 2 nd degree or master's degree. The 25-34 group accounts for $17.4 \%$, mainly consisting of students studying while working or having a doctorate. The age group that is barely motivated to go to school (from 35-44 years old) accounts for $3.8 \%$.

Finding out information from the survey subjects, the author found that students who came from ethnic minority and mountainous areas account for $37.3 \%$. The number of students from districts or cities directly under the province accounts for $35.4 \%$. Meanwhile, the number of students from inner-city districts accounts for only $12.3 \%$, and the remaining localities accounts for $14.9 \%$.

\subsection{Scale testing with Cronbach Alpha and EFA.}

\subsubsection{Cronbach alpha results.}

Considering the correlation coefficient of variables - sum (adjusted) of all observed variables must meet the requirements $>0.30$ (Hair et al. 2006), in this study, the results of Cronbach alpha show that the scales are reliable. However, the reliability will be improved if the indicators with little contribution to the scale are removed. Specifically, the Cronbach alpha of the linear information system quality scale is 0.916 (after eliminated QOIS 5, QOIS 6, QOIS11, QOIS12, QOIS15); the scale of LQ of Trust is .892 (after eliminated indicators LQ1, LQ3, LQ9, LQ10); of Efficiency is .893 (after eliminated the OLE5 indicator); of Satisfaction is 0.901 , of Loyalty, is 0.766 ; So the factors will be kept to continue the EFA analysis procedure.

\subsubsection{EFA analysis results.}

The KMO and Bartlett test results show that the KMO value is 0.859 , which satisfies the conditions $(0.5$ $<\mathrm{KMO}<1$ ), showing that the data is suitable for exploratory factor analysis. The Bartlett test gives the Sig value. $<005$, showing that the factors are linearly correlated with each other in the population (Nunnally \& Bernstein , 1994).

Five factors were formed after performing factor analysis and factor rotation according to the Promax method; all items have values above 0.5 . These five factors explain $59,679 \%$ of the variation in the data.

\subsubsection{Test the difference between groups of students.}

The study uses the independent sample T-Test for gender variables and the one-way ANOVA test for age variables, study hours, and residence to determine whether there is a mean difference between qualitative variables and satisfaction variables. 
Nguyen, T.

QUALITY OF HIGHER EDUCATION ONLINE TRAINING, STUDENT SATISFACTION AND LOYALTY IN THE CONTEXT OF THE COVID-19 PANDEMIC. A VIETNAMESE PERSPECTIVE

The results show that:

TABLE 3. THE ANOVA TEST RESULT

\begin{tabular}{|c|c|c|c|}
\hline Characteristics & sig & Mean \\
\hline Gender & 0.38 & There was no statistically significant difference in satisfaction for students of different \\
\hline Age & 0.31 & There is no statistically significant difference in satisfaction for students of different \\
age groups
\end{tabular}

Source: Authors' own conception

\subsubsection{Testing the scale model with CFA.}

After completing the EFA exploratory factor analysis step, we have the Pattern Matrix rotation matrix table. Using this rotation matrix result, we go to the confirmatory factor analysis (CFA) step.

If a model receives GFI, TLI, CFI values $\geq 0.9$ (Bentler \& Bonett, 1980); CMIN/df $\leq 2$, in some cases CMIN/df can be $\leq 3$ (Carmines \& Mclver, 1981); RMSEA $\leq 0.08$, RMSEA $\leq 0.05$ are considered very good (Steiger, 1990); The model is considered to have a good fit with the research data.

The results of CFA analysis for the (normalized) model are presented in Table 3 with CMIN $=98.240$ with 336 degrees of freedom and $p=0.00$, showing that this statistic is significant with sample size 316 . $\mathrm{GFI}=0.826$ is lower than the recommended $\mathrm{GFI}$, which is greater than 0.9 . But other indicators show that this model fits the market data (CFI= $0.890 ; \mathrm{TLI}=0.878 ; \mathrm{CMIN} / \mathrm{DF}=2.760$ and RMSEA=0.075).

TABLE 4. STATISTICAL INDICATORS REFLECT THE FIT OF THE MEASUREMENT MODEL

\begin{tabular}{|c|c|c|c|c|c|c|c|}
\hline Chi-square $\left(\mathrm{X}^{2}\right)$ & DF & CFI & GFI & TLI & CMIN/DF & P & RMSEA \\
\hline 684.901 & 336 & 0.936 & 0.870 & 0.928 & 2.038 & 0.000 & 0.057 \\
\hline
\end{tabular}

Source: Author's survey data and processing

Note: * $p$-value $<0.05 ;$ DF $=$ degrees of freedom; RMSEA: root mean square error of approximation; CFI: comparative fit index; GFI: goodness of fit index; TLI: Tucker-Lewis Index.

In addition, to assess convergent validity using average variance extracted (AVE), the composite reliability (CR) of each latent variable was estimated because it is a more suitable indicator of reliability than Cronbach coefficient alpha (Lin \& Lee, 2005; Raza, Qazi, \& Umer, 2016). Moreover, MaxR(H), 
Nguyen, $T$.

QUALITY OF HIGHER EDUCATION ONLINE TRAINING, STUDENT SATISFACTION AND LOYALTY IN THE CONTEXT OF THE COVID-19 PANDEMIC. A VIETNAMESE PERSPECTIVE

which refers to McDonald Construct Reliability, is also estimated. Hancock \& Mueller (2001) exemplified: "Coefficient $\mathrm{H}$ describes the relationship between the latent construct and its measured indicators... coefficient $\mathrm{H}$ is unaffected by the sign of indicators loadings, drawing information from all indicators in a manner commensurate with their ability to reflect the construct."

Table 2 shows that the composite reliability (CR) of all the three latent constructs is greater than 0.70 , and the average variance extracted (AVE) exceeded 0.50 , showing excellent construct reliability and convergent validity, respectively (Byrne, 2010). Besides, the square root of the AVE shown on diagonals in bold faces is greater than the rest of the inter-construct correlations (see Table 2). Hence, the discriminant validity between the five latent constructs is also established (Fornell \& Larcker, 1981). In this study, the factors in the model ensure validity and reliability, detailed in Table 5.

TABLE 5. CFA MODEL- RELIABILITY AND VALIDITY

\begin{tabular}{|c|c|c|c|c|c|c|c|c|c|}
\hline & $\mathrm{CR}$ & AVE & MSV & $\operatorname{MaxR}(\mathrm{H})$ & QOIS & OLE & $\mathrm{LQ}$ & SS & LY \\
\hline QOIS & 0.920 & 0.538 & 0.117 & 0.929 & 0.734 & & & & \\
\hline OLE & 0.894 & 0.588 & 0.067 & 0.916 & $0.227^{\star \star *}$ & 0.767 & & & \\
\hline $\mathrm{LQ}$ & 0.894 & 0.584 & 0.058 & 0.899 & 0.001 & 0.099 & 0.764 & & \\
\hline SS & 0.897 & 0.690 & 0.176 & 1.022 & $0.342^{* * *}$ & $0.258^{* * *}$ & $0.242^{\star * *}$ & 0.831 & \\
\hline LY & 0.778 & 0.639 & 0.176 & 0.812 & $0.228^{\star \star *}$ & $0.248^{* * *}$ & $0.183^{\star * \star}$ & $0.419^{\star \star \star}$ & 0.799. \\
\hline
\end{tabular}

Source: Author's survey data and processing

\subsection{Theoretical model testing}

The linear structural model analysis method (SEM) was used to test the research model. Therefore, any concept estimation results that are not statistically significant at the $90 \%$ confidence level will be excluded from the model one by one.

Research results are shown in figure 2 and detailed in Table 6. 
Nguyen, T.

QUALITY OF HIGHER EDUCATION ONLINE TRAINING, STUDENT SATISFACTION AND LOYALTY IN THE CONTEXT OF THE COVID-19 PANDEMIC. A VIETNAMESE PERSPECTIVE

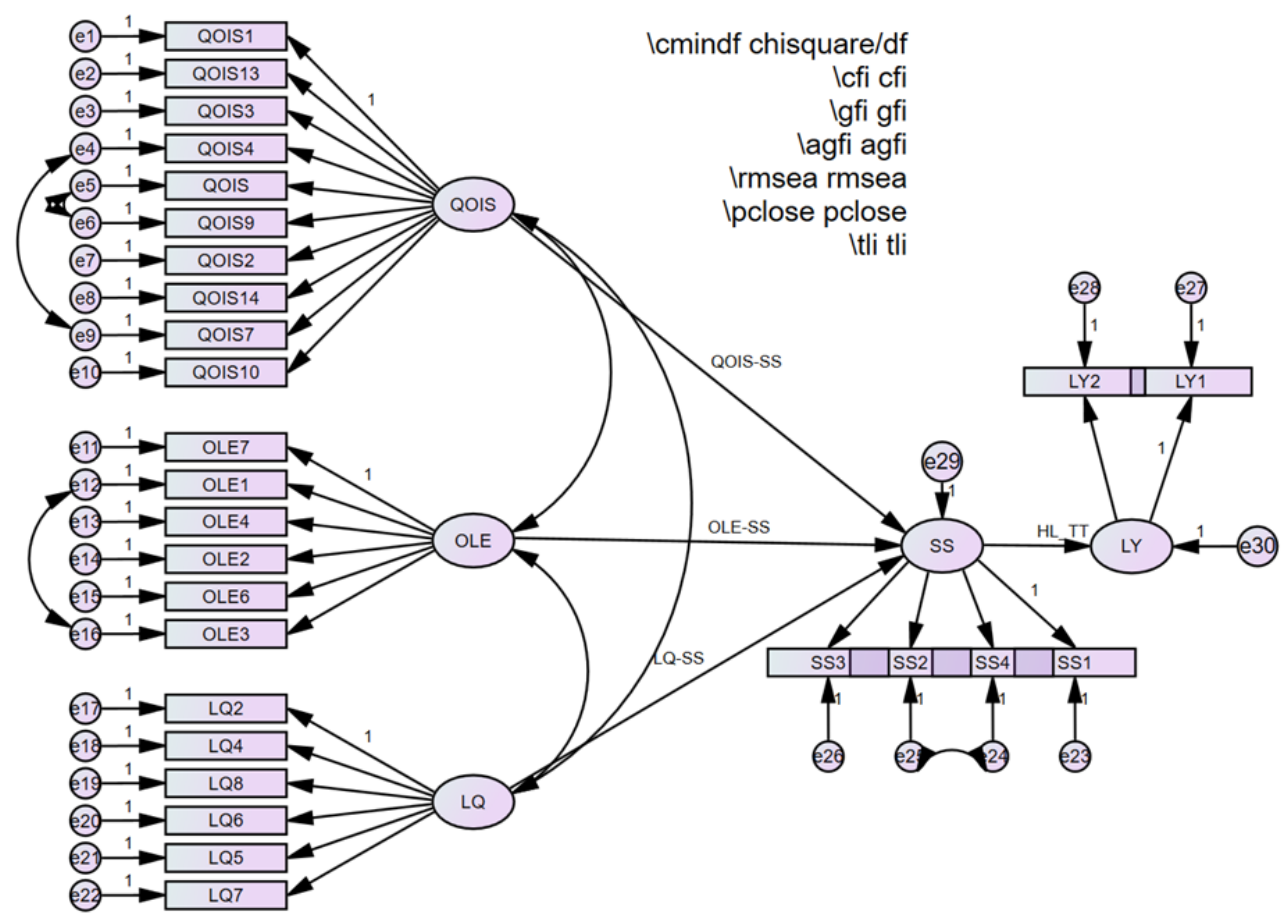

FIGURE 2. FINAL SEM MODEL

Source: Author's survey data and processing

TABLE 6. HYPOTHESES TESTING RESULTS

\begin{tabular}{|c|c|c|c|}
\hline Hypotheses & Coef & P-value & Results \\
\hline QOIS has a direct effect on SS & 0.339 & ${ }^{* * *}$ & Supported \\
\hline OLE has a direct effect on SS & 0.188 & 0.002 & Supported \\
\hline LQ has a direct effect on SS & 0.297 & ${ }^{* * *}$ & Supported \\
\hline SS has a direct effect on LY & 0.375 & ${ }^{* * *}$ & Supported \\
\hline QOIS has an indirect effect on LY & 0.127 & 0.001 & Supported \\
\hline LQ has an indirect effect on LY & 0.111 & 0.001 & Supported \\
\hline OLE has an indirect effect on LY & 0.070 & 0.003 & Supported \\
\hline
\end{tabular}

Source: Author's survey data and processing

We see that the P-values of all factors have $p<0.05$, so these variables influence satisfaction and loyalty. The $\mathrm{P}$-value of the satisfaction factor is also $<0.05$, so satisfaction also has a real influence on loyalty. The weights (unnormalized) of the independent factors all have positive signs, showing that these factors positively affect satisfaction. The dependent variable is loyalty, which shows that it also positively affects satisfaction. 
The R-squared value of SS is $0.205=20.5 \%$, so the independent variables affect $20.5 \%$ of the variation of SS. Similarly, $R$-squared of $L Y$ is $0.185=18.5 \%$, so the independent variables affect $18.5 \%$ of variation of $L Y$.

\subsection{Discussion}

From the results of data analysis, the properties of factors such as ease of login, security, update ability, and support services in the quality of the online system are not fully supported. Some examples are factors such as: not having a precise arrangement of information on online applications, not high security, the support admin of the online application lacking enthusiasm and professionalism in informing learners and providing support when needed. In addition, students rated the teacher's responsiveness as not high, and the assessment of the final exam was unfair, inaccurate, and the difficulty and length of the exam were inappropriate. Other than these, the factors of online learning effectiveness or satisfaction and loyalty are satisfactory to students. This result is completely consistent with previous studies of Moutinho \& Smith (2000). Another significant result of the study is that satisfaction is proportional to loyalty, which means the greater the satisfaction, the higher the loyalty, which is similar to the finding of Armstrong \& Boon Seng (2000).

Regarding demographic factors, the topic has shown that gender and age have no statistically significant difference to student satisfaction. However, the demographics' final results showed statistically significant differences between school hours and photo residences for satisfaction. As for the place of residence, most of the survey respondents are from mountainous areas, ethnic minority areas, border areas, and islands, so internet conditions are relatively poor and unstable. Moreover, in the context of the pandemic, the reduction of working hours of human resources to ensure safety has caused obstacles when the internet connection has problems and there is a lack of staffing to overcome. Finally, household economic conditions may not allow for personal electronic devices, which is also a significant barrier in online learning.

Regarding study hours, it is relatively complex for the groups of 35-44-year-olds to learn while working online, especially in accessing electronic media because of the awkwardness in accessing the interface and the space barrier when something goes wrong, so learning online about a particular aspect will be disadvantageous to this group of people. However, it is suitable for the group under 20 years old if they study for less than 5 hours per day. Therefore, the evaluation of the difference of demographic characteristics will be the premise for deciding the loyalty of learners.

The results of the data analysis reflect some aspects of Vietnam's reality in university online training, specifically: 
Firstly, considering the actual context in Vietnam today, there are many workers in industrial zones that are employed as unskilled workers. Thus, in 10 to 15 years, when unskilled labor is exhausted, wages cannot increase forever, families and children make labor productivity less, they will be pushed out of the labor market. Then their life will be very precarious because their starting point is untrained, and they do not have any jobs available for them. Having escaped from the countryside and now returning to work as farmers, they also have difficulty when tools and land are not available. Agriculture is now organic agriculture, requiring knowledge. Only modern education, through online education, can help them get retrained. Moreover, if universal education needs to be the cheapest and fastest, it must use technology.

Vietnam is a developing country, so the traditional rural areas are being transformed into new rural areas with the government's help of sustainable poverty reduction policies. Therefore, regions with difficult economic conditions are now able to invest in technological means for education. Due to the effects of the covid pandemic, government policy packages to support people are necessary; however, it will lead to the situation of the economy being "flooded" with money and thus, the risk of a public debt crisis due to the government pumping out too much money, which is reflected through inflation and illiquidity of the economy. Moreover, facing the stagnation of the global economy, any individuals, institutes, and governments of any countries are hesitant with any investment. Nevertheless, in the innovation period, we have an essential task to promote technology in education, and to bring information about education to people in all different regions when there is a need to learn. Furthermore, technology will help us train a generation of digital citizens. They will be citizens who have good professional knowledge, along with good consciousness, attitudes, and behaviors. In the digital and technological era, attitudes and behaviors are equally important, even more important than qualifications, because attitudes and behavior will shape the personality of each citizen of that country. Therefore, investment in technology needs to be popularized on a large scale from plains to mountainous areas as well as border and island areas. Unfortunately, this has not been clearly shown in remote areas, especially in ethnic minority areas in Vietnam.

Second, the quality of fixed broadband service is not high. A network operator that meets consumer satisfaction requires a stable network connection, data download speed, data posting speed, and service packages suitable for each residential area. However, the research results have reflected the inadequacy of the internet experience in some localities of Vietnam.

Third, the issue of network security and student privacy is not guaranteed. This existence shows the loose management from the educational institution. The access security of online classes is low, and the use of public IDs and passwords makes it possible for anyone to join the class. Some universities use free software, so their control is limited. If the educational institution uses copyrighted software to 
control access and there is a cooperation between educational institutions and information safety and network security management agencies, this problem will be minimized. These agencies will create adequately strong deterrent sanctions and strictly handle lousy behaviors towards online teaching, aiming to build a safe space for online classes.

Fourth, the sole purpose of higher education is to train quality human resources, and the learning outcomes of students assess this. However, despite many efforts and changes to adapt to the online form of training, students still consider the assessment test inappropriate. The main reason is that the assessment form is still implemented as face-to-face, but in the online form, leading to the low and inefficient responsiveness in terms of space, time, and operation, and thus, leading to unfairness.

Fifth, the author believes that the most crucial point in online teaching and learning lies in the teacher. Many assessments of the responsiveness and the flexibility in the teaching of the lecturers are not high. Understandably, besides young lecturers who have quick access and adaptation to technology, many lecturers in basic subjects who are familiar with traditional teaching methods such as philosophy, political economy, etc. has difficulty in transferring knowledge because the characteristics of the specialization and knowledge are difficult to condense, causing boredom in students' knowledge acquisition. It can be said that online training is both a challenge and an opportunity for lecturers. Changing teaching methods is changing the professional thinking.

Most students volunteer and are satisfied with online training; satisfaction leads to a high consensus that students will recommend this form of training to others. This satisfaction is the premise to promote the brand image of the higher education institution.

\section{CONCLUSION}

\subsection{Limitation}

This study is conducted based on learners' perspectives, and the authors choose a large university, comprising many member schools for diverse research. Besides, the authors' purpose is to show the inadequacy of online training in areas with low economic conditions compared to other regions, and from there, develop a more practical orientation for ethnic minorities and remote areas, islands, and borders. However, the study has some limitations:

First, because the study only focused on member schools of one region, not the whole country. Therefore, research results cannot be representative of a country's higher education. The evaluation of research results is specific to a university, so the proposed solution is suitable for areas with similar difficult socio-economic conditions. 
Second, under certain conditions, research only analyzes what is most direct and has not presented specific databases as the basis (rotating matrix table, unstandardized CFA analysis) for the main research sections.

\subsection{Solutions}

Based on the research results and the situation of Vietnam in the current 3rd wave of Covid with a severe lack of vaccines, universities cannot return to face-to-face learning during this time. Therefore, the author proposes groups of solutions to improve the quality of online training at higher education institutions:

\section{Guarantee financial support from the government}

The covid pandemic has radically impacted the economies of each country, and higher education institutions are no exception. Although many schools have moved towards autonomy, in the general situation, when switching from face-to-face training to online, the tuition policy has also changed. In addition, the disruption and restructuring in supply chains, value chains, and the reversal of FDI inflows lead to financial deficits in universities, requiring the government to come up with financial rescue packages to support higher education institutions to ensure training.

In addition, the government can provide student support packages through loans from policy banks with a $0 \%-0.5 \%$ interest rate for each loan package, and the loan contract maturity is as soon as the student has a job and no later than 12 months after graduation.

\section{Ensure unified information technology infrastructure}

In online training, teaching and learning activities are carried out through information technology (IT) tools. Besides, IT infrastructure (internet network, bandwidth, cost...) also plays a significant role because it directly and significantly affects the progress and quality of learning.

Therefore, ensuring IT infrastructure, namely server infrastructure, Internet, speed, transmission lines, bandwidth, and software systems, to meet the ability to access and store learning resources and data that serves teaching and learning purposes plays an important role in improving the quality of training. To fulfill this requirement, the training institution needs to manage the effective use of IT infrastructure. Firstly, implement security, maintenance, and preservation of the hardware and software equipment system for stable, safe, and effective use. Secondly, simultaneously research, develop, and update new technologies to meet the needs of users through specific measures such as

- organizing regular monitoring of the use of IT infrastructure.

- building a team of administrators and software developers with professional qualifications to research, develop and upgrade the system.

- periodically evaluating the exploitation and use of hardware and software systems in order to have solutions to use more effectively promptly and in accordance with the development of IT; 
- maintaining a good funding source for maintenance, investment in upgrading the quality of the system.

From there, educational institutions can use a unified online training platform. The training quality management department of each unit also controls the teaching quality of the lecturers and monitors the learning process of students, promptly adjusting and improving the quality of education.

\section{Ensure diverse learning resources, meet professional and technical quality}

Training institutions need to manage the design, implementation, and development of learning materials; manage the work of appraisal and approval; manage the exploitation and operation of the learning materials system; manage the periodic and regular review, correction, and update of e-learning materials of all subjects.

The management adopts measures such as: promulgating standard documents, e-learning development process, organizing training on building and updating e-learning materials for lecturers, design staff, and technical staff.

In many cases, the lesson content should not be too abstract and complicated, especially related to practice that IT cannot show or show inefficiently.

\section{Building and developing a teaching staff in terms of both quantity and quality}

Unlike traditional teaching methods, online teaching requires lecturers to have some skills suitable for this method, especially skills in applying and integrating IT in constructing, designing lessons and programs as well as teaching and interacting with learners through IT devices.

Accordingly, training institutions need to review the current state of lecturers in terms of structure, number, and capacity of lecturers, thereby developing training plans, fostering, and training them; evaluate the teaching activities of lecturers by issuing quality guidelines when teaching online, collecting learners' opinions, and activities of functional departments in training institutions; ensure the classroom environment has enough working facilities and tools for online interaction with learners. At the same time, there should be a remuneration system for lecturers whose performances are commensurate with the work requirements of high expertise, good skills, and creativity.

For example, at the beginning of a new lesson, teachers need to provide operational instructions, goalbased learning methods, and content to help guide the implementation of learning tasks. At the same time, they should participate in supporting learners' learning activities and give positive feedback to enhance learners' initiative and interaction. The lecturer acts as a guide in performing learning tasks, orienting learners to actively perform learning operations to form competencies such as practice or application, and regularly consulting learners' feedback. In online teaching, through the student's activity 
scores in each chapter and the results of the exercises, instructors will monitor the effectiveness of teaching activities and promptly improve the teaching content to achieve the lesson's objectives.

\section{Require initiative and equips learners with IT skills}

With online learning, because learners do not directly go to class but self-study mainly, the quality of training depends significantly on the self-study ability of learners. In other words, this method requires learners to be very active in studying materials, interacting with teachers, and interacting with other learners to acquire knowledge.

In addition, learners must have a specific IT level due to the characteristics of learning mainly through IT tools to access knowledge, especially skills in using computers and exploiting digital resources on the network, and they need to increase responsibility and initiative to ensure maximum exploitation of the benefits that IT brings to the learning process.

Besides the subjective and objective existing limitations of the IT platform, the adaptability of teachers, learners, and online training shows advantages such as synchronization, flexibility, proactive orientation, customized learning, interaction, and cooperation, as well as easy access to learners. In the spirit of solid innovation, profound experience, and highly feasible solutions corresponding to the conditions of each training institution, the organization of online teaching will undoubtedly become more and more effective. Online education complements face-to-face teaching, combined together as a "blended learning" mode of training. This type of learning is also the general trend of global education.

\section{REFERENCES}

Abdalla, I. (2007). Evaluating effectiveness of e-blackboard system using TAM framework: A structural analysis approach. Association for the Advancement of Computing in Education, 15(3), 279-287.

Ali, A., \& Ahmad , I. (2011). Key Factors for Determining Students' Satisfaction in Distance Learning Courses: A Study of Allama Iqbal Open University. Contemporary Educational Technology, 2(2), 118-134. doi:10.30935/cedtech/6047

Ali, W. (2020). Online and Remote Learning in High er Education Institutes: A Necessity in light of COVID-19 Pandemic. Higher Education Studies, 16(2), 10.

Arambewela, R., \& Hall, J. (2006). A comparative analysis of international education satisfaction using servqual. Journal of Services Research, 6, 141-163.

Armstrong, R., \& Boon Seng, T. (2000). Corporate-customer satisfaction in the banking industry of Singapore. International Journal of Bank Marketing, 18(3), 97-111. doi:10.1108/02652320010339617

Belawati, T., \& Baggaley, J. (2009). Policy and Practice in Asian Distance Education. SAGE Publications India.

Bentler, P., \& Bonett, D. G. (1980). Significance tests and goodness of fit in the analysis of covariance structures. Psychological Bulletin, 88(3), 588-606. doi:10.1037/0033-2909.88.3.588 
Bloemer, J., Ruyter, K., \& Peeters, P. (1998). Investigating drivers of bank loyalty: the complex relationship between image, service quality and satisfaction. International Journal of Bank Marketing, 16(7), 276-286. doi:10.1108/02652329810245984

Bowen, J., \& Chen, S.-L. (2001). The relationship between customer loyalty and customer satisfaction. International Journal of Contemporary Hospitality Management, 13(5), 213-217.

Browne, B., Kaldenberg, D., Browne, W., \& Brown, D. (1998). Student as Customer: Factors Affecting Satisfaction and Assessments of Institutional Quality. Journal of Marketing for Higher Education, 8(3), 1-14. doi:10.1300/J050v08n03_01

Byrne, B. M. (2010). Multivariate applications series. structural equation modeling with AMOS: Basic concepts, applications, and programming. New York: Taylor \& Francis Group. doi:10.4324/9780203805534

Carmines, E., \& Mclver, J. P. (1981). Analyzing Models with Unobserved Variables: Analysis of Covariance Structures. (G. W. Bohrnstedt, \& E. F. Borgatta, Eds.) Social Measurement, 65-116.

Chute, A., Thompson, M., \& Hancock, B. (1999). The McGraw-Hill handbook of distance learning. New York: The McGraw-Hill Companies, Inc, NY.

Delone, W. H., \& McLean, E. R. (2003). The DeLone and McLean Model of Information Systems Success: A Ten-Year Update. Journal of Management Information Systems, 19(4), 9-30. doi:10.1080/07421222.2003.11045748

Dhawan, S. (2020). Online Learning: A Panacea in the Time of COVID-19 Crisis. Journal of Educational Technology Systems, 49(1), 5-22. doi:10.1177/0047239520934018

Fornell, C., \& Larcker, D. F. (1981). Evaluating Structural Equation Models with Unobservable Variables and Measurement Error. Journal of Marketing Research, 39-50. doi:10.1177/002224378101800104

Garvey, A., García, I., Otal Franco, S., \& Fernández, C. (2021). The Psychological Impact of Strict and Prolonged Confinement on Business Students during the COVID-19 Pandemic at a Spanish University. Int. J. Environ. Res. Public Health, 18(4), 1710. doi:10.3390/ijerph18041710

Griffin, R. W. (1996). Management, 5th Edition. Houghton: Mifflin Company, Boston.

Grossman, R. (1999). Relational versus discrete exchanges: The role of trust and commitment in determining customer satisfaction. Journal of Marketing Management, 9(2), 47-58.

Han, S., \& Beak, S. (2004). Antecedents and Consequences of Service Quality in Online Banking: An Application of the SERVQUAL Instrument. Advance in Consumer Research, 31, 208-214.

Hancock, G., \& Mueller, R. (2001). Rethinking construct reliability within latent variable systems. Scientific Software International, Inc., USA.

Helgesen, Ø., \& Nesset, E. (2007). What accounts for students' loyalty? Some field study evidence. International Journal of Educational Management, 21(2), 126-143. doi:10.1108/09513540710729926

Hill, F. (1995). Managing service quality in higher education: the role of the student as primary consumer. Quality assurance in Education, 3(3), 10-21.

Ho, C.-L., \& Dzeng, R.-J. (2010). Construction safety training via e-Learning: Learning effectiveness and user satisfaction. Computers \& Education, 55(2), 858-867. doi:10.1016/j.compedu.2010.03.017

Jun, M., \& Cai, S. (2001). The key determinants of Internet banking service quality: a content analysis. International Journal of Bank Marketing, 19(7), 276-291. 
Lee, M.-C. (2010). Explaining and predicting users' continuance intention toward e-learning: An extension of the expectation-confirmation model. Computers \& Education, 54(2), 506-516. doi:10.1016/j.compedu.2009.09.002

Leslie, L., \& Brinkman, P. (1987). Student price response in higher education. Journal of Higher Education, 181-204.

Liaw, S.-S. (2008). Investigating students' perceived satisfaction, behavioral intention, and effectiveness of e-learning: A case study of the Blackboard system. Computer \& Education, 51(2), 864-873. doi:10.1016/j.compedu.2007.09.005

Likert, R. (1932). A Technique for the measurement of attitudes. Archives of Psychology.

Lin, H.-F., \& Lee, G.-G. (2005). Impact of organizational learning and knowledge management factors on e-business adoption. Management Decision, 171-188.

Moutinho, L., \& Smith, A. (2000). Modelling bank customer satisfaction through mediation of attitudes toward human and automated banking. International Journal of Bank Marketing, 18(3), 124-134. doi:10.1108/02652320010339699

Nunnally, J., \& Bernstein, I. (1994). Psychometric theory. New York.

Oliver, R. L. (1997). Satisfaction: A behavioral perspective on the consumer. London and New York: Routledge Taylor\&Francis Group.

Parasuraman, A., Zeithaml, V., \& Berry, L. (1985). A conceptual model of service quality and its implications for future research. Journal of Retailling, 64(1), $12-40$.

Parker, C., \& Ward, P. (2000). An analysis of role adoptions and scripts during customer-to customer encounters. European Journal of Marketing, 34(3/4), 341-359.

Peterson, R., \& Merunka, D. (2014). Convenience samples of college students and research reproducibility. Journal of Business Research, 67(5), 1035-1041. doi:10.1016/j.jbusres.2013.08.010

Ramírez-Hurtado, J., Hernández-Díaz, A., López-Sánchez, A., \& Pérez-León, V. (2021). Measuring Online Teaching Service Quality in Higher Education in the COVID-19 Environment. International Journal of Environmental Research and Public Health, 18(5), 2403. doi:10.3390/ijerph18052403

Raza, S. A., Qazi, W., \& Umer, A. (2016). Facebook Is a Source of Social Capital Building Among University Students: Evidence From a Developing Country. Journal of Educational Computing Research, 55(3), 295-322. doi:10.1177/0735633116667357

Richard, H., \& Haya, A. (2009). Examining student decision to adopt web 2.0 technologies: theory and empirical tests. Journal of computing in higher education, 21(3), 183-198.

Sher, A. (2009). Assessing the relationship of student-instructor and student-student interaction to student learning and satisfaction in Web-based Online Learning Environment. Journal of Interactive Online Learning, 8(2), 102-120.

Steiger, J. (1990). Structural model evaluation and modification: An interval estimation approach. Multivariate Behavioral Research, 25, 173-180.

Thomas, M. S., \& Rogers, C. (2020). Education, the science of learning, and the COVID-19 crisis. Prospects, 49, 87-90. doi:10.1007/s11125-020-09468-z

Verduin, J., \& Clark, T. (1991). Distance Education: The Foundations of Effective Practice. San Francisco: Jossey-Bass.

Vlachopoulos, D. (2020). COVID-19: Threat or opportunity for online education? Higher Learning Research Communications, 10. doi:10.18870/hlrc.v10i1.1179

Zeithaml, V. (1988). Consumer Perceptions of Price, Quality, and Value: A Means-End Model and Synthesis of Evidence. Journal of Marketing, 52, 2-22. 
Nguyen, $T$.

QUALITY OF HIGHER EDUCATION ONLINE TRAINING, STUDENT SATISFACTION AND LOYALTY IN THE CONTEXT OF THE COVID-19 PANDEMIC. A VIETNAMESE PERSPECTIVE

Zhuo, L., Wu, Q., Le, H., Li, H., Zheng, L., Ma, G., \& Tao, H. (2021). COVID-19-Related Intolerance of Uncertainty and Mental Health among Back-To-School Students in Wuhan: The Moderation Effect of Social Support. Int. J. Environ. Res. Public Health, 18(3), 981. doi:10.3390/ijerph18030981 